\title{
Learning Culture as an Effort to Increase Interest in Continuing Studies
}

\author{
Monica Farra Diba \\ Graduate School \\ Universitas Negeri Yogyakarta \\ Yogyakarta, Indonesia \\ moniquefarra@gmail.com
}

\author{
Trie Hartiti Retnowati \\ Graduate School \\ Universitas Negeri Yogyakarta \\ Yogyakarta, Indonesia \\ trie_hartiti@yahoo.com
}

\begin{abstract}
The purpose of this research is to understand the learning culture to increase interest in further study. The problems of this research are the lack of interest of students of SMP Negeri 1 Saptosari serves to continue the study. The methods used in the research was the qualitative method. The technique of data collection is done with the interview, observation and documentation. Data were analyzed with the reduction of the data, the presentation of the data and the withdrawal of the conclusion. The research results showed that the need for the development of a culture of learning to encourage the interest of students to continue their studies. Efforts have been made to develop a culture of learning in schools is motivating students, develop learning methods, optimizing infrastructure, establish a good relationship with residents, Schools and so on. The results of this research are expected to be entered in order to develop a culture of learning in the school so that students can study interest increased.
\end{abstract}

Keywords - learning culture; student interest; interest in continuing studies.

\section{INTRODUCTION}

Education is a process experienced by everyone who plays an important role in one's life. Education has a big influence on the progress of the nation as indicated by the quality of education. Populations with higher levels of education will have the ability to adapt to science and technology compared to the higher education population. Through education can be born humans can build themselves and society.

The development of the culture of junior high school learning is in line with the direction of education policy in Indonesia. This is evident in Act Number 20 year 2003 concerning Article 3 of the National Education System, which states that national education is intended to develop the potential of students to become human beings who believe and fear God Almighty, noble, healthy, knowledgeable, capable, creative, independent, and become a democratic and responsible citizen to educate the life of the nation. National education goals are the basis for the development of a learning culture. Development of learning culture can be done through the development of the school community environment. The students live and develop in the social environment of the school community, so that the development of a learning culture can only be done in the social environment of the school community concerned.
Learning culture is a reflection of the quality of school life that grows based on the enthusiasm and values adopted by the school, environment, atmosphere, taste, nature and the school climate that is able to develop intelligence, student skills expressed in collaboration between school members in discipline, responsibility and motivation for learning. Learning culture is a view of life shared by the school community which includes ways of thinking, behavior, attitudes, values that are reflected both in physical and abstract forms, especially those related to learning outcomes.

In recent years there has been a shift in many areas of educational education and research practices from focusing on education to focusing on learning. One reason behind this shift is the idea that language learning seems more open and not too limited than the language of education. While the language of education tends to focus on their educational activities and intentions, the language of learning makes it possible to focus on what children and adolescents themselves do, that is, on how they learn, both in relation to the activities of educators, but often also outside or outside of certain educational settings, scenarios and structures. Therefore, over the past decade educational researchers have developed a variety of different approaches to learning studies, both in formal education settings and in various other informal and informal settings, such as family, work, local communities, and the wider community.

The goal of national education can be realized if various educational problems can be addressed properly. One of the problems with National Education that has yet to be resolved is the dropout rate and the low interest in junior high school students going to high school level. Many districts and provinces have waived the cost of education in secondary schools, but in some regions, it is still permissible to collect education fees to cover the lack of the education budget. The 12-year compulsory education program has not been well realized and does not even have a legal umbrella that encourages it to be realized.

Various literacies reveal that the problem of interest in continuing studies is influenced by factors in the family's socio-economic status. The work of parents, the acquisition of parents, parental education and the position of parents in the community are considered to influence students' interest in continuing their studies. The higher the family's socio-economic 
status, the higher the person's interest in continuing their studies, and vice versa. Often, we focus on economic factors, while student learning in schools also affects the interest in continuing studies.

Children get the opportunity from parents, teachers and others to learn about what their cultural groups consider to be interests. The interests they pursue must be in accordance with their culture or group, and have no right to pursue opportunities, which are not suitable for them by their cultural groups [1]. Cultural groups influence children to determine their interests. The existence of children in certain cultural groups also affects their learning interests.

Culture is a system of values and beliefs that interact with people in an organization, organizational structure and control systems that produce behavioral norms [2]. Culture is obtained through a learning process by a person or group of people in the environment who can develop into a learning culture. Learning culture is a human creation that appears as a learning behavior, used by a person or group of people to show actions and differences in the school environment.

\section{LITERATURE REVIEW}

The purpose of this literature review is to provide a foundation from which to consider relationships that have so far been poorly understood between interesting students and sustainable learning and student learning culture.

Understanding the concept of learning culture cannot be separated from understanding the cultural meaning and meaning of learning. Culture is strongly influenced by the values and norms believed by a person or group of people in carrying out activities to achieve certain goals. While the notion of learning can be defined from various theoretical perspectives, the point of which is that learning causes various changes in a person. Learning is the process of gaining knowledge and skills, so that students experience change both in the cognitive, psychomotor and affective domains. So that it can be said that learning culture is the attitude and behavior of a person or group of people in conducting learning activities that are based on certain values and norms to achieve defined goals and objectives.

Tharp states that culture involves three basic human activities consisting of: what people think, what people do, and what people make [8]. Then some common characteristics arise such as: shared culture, learning culture, and others. Which is transmitted across generations in a formal and informal manner [3]. Culture is accepted and reproduced by human activities, often collected, but also by individual activities. Every place where people act and get involved has learning, where learning takes place [4].

Learning occurs in many learning cultures from time to time. One can move in the context of peripheral participation to the center, from newcomers to full members, and move between learning cultures. For example, from institution to home and family or work, direct people to change over time. The concept of learning culture is now called an educational culture, which explains the complexity in it. Learning be a more lasting change and not a result of maturation [5]. Each of us is a product of a particular "learning culture" that provides norms, habits, and expectations that influence our thoughts and behavior as students and educators. But we tend to specialize in this culture as it is until it is confronted with a contrasting learning culture that challenges our beliefs, intentions and practices [6]

Culture of learning is a learning habit that is carried out continuously and is done because the desires of oneself are not the result of coercion. Cultural learning also involves students about the cultural learning environment carried out by the learning methods applied by the teacher, the relationship between students and teachers and students who walk in the school. The interest of students who study culture makes students who have a great interest in continuing their studies will need to learn more and have a good learning culture. This is supported by the Throndike statement which states that position differences are learning among other variables [7]. With learning culture indicators consisting of environmental influences, practice, and habits, depending on good conditions, it can be adjusted to students' interest to improve their studies to high school will increase.

Culture of Learning According to Rusyan learning culture is a series of activities in carrying out learning tasks carried out [8]. We make learning as a habit, where if the habit is not implemented, it means breaking a value or standard that exists, and making learning as a hobby and pleasure, so that motivation to learn arises from within ourselves, which ultimately increases learning productivity. Learning culture does not only appear in the school environment but in the family environment and social environment.

\section{A. Culture of Learning in Schools}

The school environment plays an important role for the development of student learning. This environment includes the school's physical environment, such as the school environment, existing learning facilities and infrastructure, learning resources, learning media and some of them. A social environment that involves the relationship between students and friends, teachers and other school staff. The school environment also concerns the academic environment, namely the atmosphere and implementation of teaching and learning activities and various extracurricular activities.

\section{B. Culture of Learning at Home}

Psychological climate is related to affective atmosphere or feeling that includes family. A healthy psychological climate is characterized by love, trust in trust, openness, intimacy, a sense of belonging among family members. A healthy psychological climate will support the smoothness and success of learning, 
because such an atmosphere can provide calm, joy, confidence, encouragement for achievement.

\section{Culture of Learning in the Community}

Culture of learning related to society, peer factors and activities in society can also influence children's learning activities. Outside school activities are good for children's development. However, not all activities can help children. If a child does too many activities outside the home and outside of school, while he cannot divide his learning time, he will automatically endanger the child because his learning activities are disrupted.

The culture of student learning is possible because of environmental influences. In other words, environmental conditions contribute to shaping one's learning culture. When students see a friend doing certain learning activities, then it can be seen in terms of positive or negative. If students see this learning activity negatively, then the activity will not be carried out or carried out uncomfortably. However, if learning activities are positive, then this will be done with satisfaction. when learning is considered a fun and satisfying activity, then someone will continue to do this activity in an adventurous and sustainable manner. students will continue to be motivated to study until college when they have an interest in learning activities. therefore, the culture of learning in schools, homes and social environments must be developed so that students continue to be interested and motivated to continue their studies to a higher level.

\section{DATA COLLECTION AND ANALYSIS}

This study uses a qualitative approach. Data collection is done by semi-structured interviews. Then direct observation in the field and documentation. This study focused on how the students, teachers and school staff aspects of implementing a learning culture. Not only focused on student activities, but also on how the relationship between students, teachers and school staff. other than that, it also requires observing the facilities and infrastructure that support learning activities. This is done in order to get a detailed description of the learning culture at school

The total participants in this study were 24 people (10 male students, 10 female students, 2 teachers, 1 school principal and 1 staff). The study was conducted by conducting direct interviews and recording the interview. Interviews were conducted in schools with a duration of 15-60 minutes. After that, the data that has been obtained is data reduction. Then the data in the analysis are then made conclusions.

\section{IV.FINDINGS}

In this section, we present the findings of the synthesis of students and teachers who have participated. We first examine the data collected from each school individually. In this paper, we report several findings relating to the learning culture and the interest of students continuing school.

Based on data that has been analyzed, we find that learning culture is caused by several factors so that it can influence the interest in continuing studies. Some of the factors that influence the process of learning culture include: 1) factors that come from internal (psychological factors) children and 2) factors that originate from external (School environment).

\section{A. Student internal factors}

This aspect of internal factors means something that arises from within the individual or from internal encouragement so that they have maximum learning power (prime) in gaining knowledge and learning experience, there are two things internal aspects that affect students' learning motivation, namely:

\section{1) Autosuggestions}

Autosuggestions are original learning ideas that thrive and develop and internalize in a person into new behaviors about learning. This autosuggestion can be a positive statement about ideas and concepts that can lead one to focus and concentrate in learning. Positive statements about ideas and concepts that can affect one's learning culture such as; learning can deliver success; learning can open a broader horizon of knowledge, a high and strong spirit of learning will have an impact on the success of learning and be able to compete with one's own friends. Positive ideas and self-concepts about learning can also affect a person's confidence in designing learning programs during the learning activities at the level and type of education, such as; if learning is as strong as possible without any interference then in each stage of the evaluation of learning in the school will be passed well without any subjects scattered and not passing the exam. It is not easy to generate autosuggestion in each student in order to have a high and resilient learning culture. Because, not all children have the same learning ability, familiarize children with concrete and logical thinking and provide deep spiritual questions that are factors that can increase self-confidence in children.

\section{2) Past learning experiences}

Past learning experiences are also a source of inspiration for changes and developments in the culture of learning for students, because experience is the best teacher who can provide corrections to mistakes and failures that have been done before. Past learning experiences about the possibility of unsuccessful learning in many ways that can be revealed so that it can change towards an effective, superior and optimal learning culture in conducting learning activities such as; (1) choosing study time so that it really does not interfere with learning needs, (2) repeating past learning experiences in arousing the concept of learning and emotions in order to be more focused and concentrated, (3) recalling positive statements about learning such as; learning is travel, a lot of learning, so much to gain knowledge and experience, learning can maintain mentality and personality, enthusiasm in learning, knowledge and memory is easy for everyone.

Positive statements about learning can encourage every individual who is just starting out and will 
develop a learning culture in every field of interest. There are still many factors that can internally influence the culture of student learning such as development and increasing age of a person influencing the culture of learning, readiness of learning is something that can absolutely influence the success of learning.

\section{B. External factors of students}

External factors are elements that accompany the existence of individuals in carrying out student learning activities, external elements that influence children's learning culture are a) concern, b) intelligent teachers, c) enough material, and d) adequate time and opportunity. The concern factor referred to here is the views and attitudes of all elements of the learning community in the school environment that have a superior quality learning paradigm so that this will always be seen by students when in the classroom about teaching methods that are truly ready and paying attention to given subjects, all assignments given to children are responded to and worked on not just finished working on the task but have the weight and breadth in its completion.

While the second element is an intelligent teacher, the presence of teachers for students is an important element, because without guidance and direction of the teacher there is no possible learning process, because the role and function of the teacher are as designers and implementers of the learning process in the classroom, enrichment processes and activities independent student learning. Smart teacher attendance is explained in the laws of teachers and lecturers called professional teachers or educators. Professional teachers are reflected in the implementation of service assignments that are characterized by expertise both in material or method and are demonstrated through their responsibilities in carrying out all their services.

\section{CONCLUSION}

This study investigates the context, that student learning culture can affect students to be able to continue their studies to a higher level (in this case junior high school students in high school). a good learning culture will create a comfortable learning environment too. Thus, motivating students to continue learning and make it a habit. teachers, parents, peers and other people can influence the choice of students to continue their studies. besides, the existence of adequate learning facilities also determines whether a learning culture is good. for that reason, the learning culture in schools must continue to be well developed so that students can drop out of school. a good learning culture also supports academic achievement students

\section{REFERENCES}

[1] E. B. Hurlock, Perkembangan Anak (Terjemahan: Metasari Dan Tjandrasa Dan Muslichah Zarkasih), Jakarta: Erlangga, 1991.

[2] P. Tika, Budaya Organisasi Dan Peningkatan Kinerja Perusahaan. PT. Bumi Aksara. Jakarta, 2006.

[3] B. M. Tharp, Defining "culture" and "organizational culture": From Anthropology to the Office. Naworth, 2009.

[4] P. Hodkinson, G. Biesta, and D. James, "Understanding Learning Culturally: Overcoming the Dualism Between Social and Individual Views of Learning". Vocations and Learning vol 1(1), 2008, pp. 27-47.

[5] G. Biesta, "From Learning Cultures to Educational Cultures: Values and Judgements in Educational Research and Educational Improvement" . International Journal of Early Childhood vol. 43(3), 2011, pp. 199-210.

[6] G. Biesta, P. Hodkinson, and D. James, "Understanding Learning Cultures". Educational Review vol. 59(4), 2011, pp. 415-427.

[7] O. Hamalik, Proses Belajar Mengajar. Bandung: Bumi Aksara, 2011.

[8] A. T. Rusyan, Budaya Belajar Yang Baik. Jakarta: PT. Panca Anugerah Sakti, 2007. 